\title{
Low levels of aluminium causing death of brown trout (salmo trutta fario, L.) in a Swiss alpine lake
}

\author{
Daniel Dietrich ${ }^{1}$ and Ch. Schlatter \\ Institute of Toxicology, Swiss Federal Institute of Technology and University of Zürich, CH-8603 \\ Schwerzenbach, Switzerland
}

Key words: Aluminium; acid water; brown trout; toxicity; stocking; alpine lakes; Lake Laiozza.

\begin{abstract}
Several attempts to stock fish in acidified alpine lakes have so far proven unsuccessful. In an effort to investigate the problems associated with the stocking of fish, the Swiss alpine Lake Laiozza was chosen for experimentation. An analysis of Lake Laiozza water revealed low ion concentrations $(0.5 \mathrm{mg} \mathrm{Ca} / \mathrm{L}$, $0.13 \mathrm{mg} \mathrm{Na} / \mathrm{L}, 0.02 \mathrm{mg} \mathrm{Cl} / \mathrm{L})$, moderate aluminium concentrations $(121 \pm 28 \mu \mathrm{g} \mathrm{Al} / \mathrm{L})$, and a moderately low $\mathrm{pH}(5.41 \pm 0.21)$. As in common practice, one and two year old brown trout were exposed in a closed keep-net in Lake Laiozza. The water of Lake Laiozza proved to be acutely toxic to the fish. Mucous clogging of the gills, gill epithelial damage, plasma electrolyte losses, and high hematocrits were the predominant symptoms observed. All symptoms observed are typical for an acute intoxication with aluminium. This stands in contrast to the generally accepted view that aluminium concentrations lower than $200 \mu \mathrm{g} \mathrm{Al} /$ $\mathrm{L}$ should not be toxic to brown trout at a pH 5.4. The low $\mathrm{Na}$ and $\mathrm{Cl}$ and low Ca concentrations in the Lake Laiozza water seem to have rendered the fish much more susceptible to aluminium intoxication.
\end{abstract}

\section{Introduction}

Acidified waters have been recognized as a problem for freshwater fisheries in Europe and North America. Intensive research resulted in the identification of aluminium (Al) as the major fish toxicant besides low $\mathrm{pH}$.

The main target organ for aluminium effects is the gill. In acidic waters $(\mathrm{pH} 4.6-5.3)$ with low levels of calcium $(0.5-1.5 \mathrm{mg} \mathrm{Ca} / \mathrm{L})$, labile $\mathrm{Al}$ between $25-75 \mu \mathrm{g} \mathrm{Al} / \mathrm{L}$ can be acutely toxic (Fivelstad and Leivestad, 1984, Rosseland and Skogheim, 1987, Skogheim and Rosseland, 1986). In addition to $\mathrm{H}^{+}$, aluminium causes the loss of plasma ions $\left(\mathrm{Na}^{+}, \mathrm{Cl}^{-}\right.$), reduces osmolality, and increased hematocrit (Muniz and Leivestad, 1980 a and 1980 b, Leivestad et al., 1980, Rosseland and Skogheim, 1984 and 1987). Beside the inhibition of osmoregulation in the gills (Wood and McDonald, 1987), aluminium exhibits a cytotoxic activity resulting in gill damage and thus inhibiting gas exchange (Dietrich and Schlatter, 1989, Dietrich, 1988, Muniz and Leivestad, 1980 b, Mallatt, 1985).

\footnotetext{
${ }^{1}$ Correspondence should be sent to: Institute of Toxicology, Schorenstrasse 16, CH-8603 Schwerzenbach/Switzerland.
} 


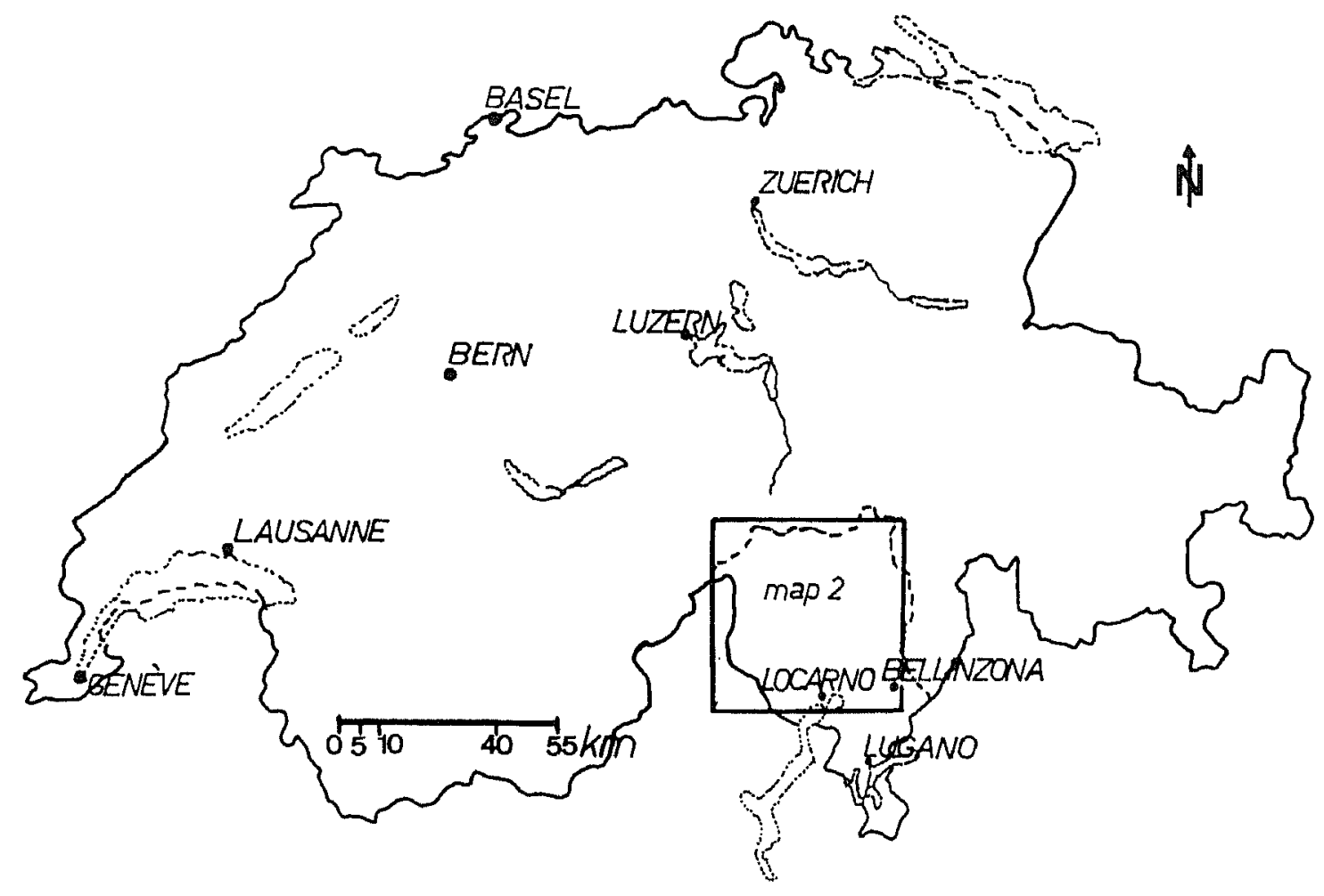

Figure 1. Overview map of Switzerland.

These toxic effects were shown to be mitigated by the presence of moderate concentrations of Ca (Brown, 1981), high concentrations of humic acids (Discroll et al., 1980, Baker and Schofield, 1982), and, just recently, high concentrations of Si (Birchall et al., 1989). No mitigating effects on Al toxicity have so far been reported for $\mathrm{Na}$ and $\mathrm{Cl}$.

The outset of our investigation was a personal communication by Marrer (1986). Marrer suveyed alpine lakes in southernmost Switzerland (figure 1) for water parameters and fish population statuses in the years 1973-1975. He found most lakes, including the lakes chosen for our study, to have healthy fish populations and water pH's ranging from approx. 6.0 to 8.1. A later study (Righetti, 1981) concentrating on the water chemistry of the lakes of the same area, showed that the water pH's had dropped considerably. Furthermore, a study designed to evaluate the effects of air pollution on alpine lakes (Barbieri and Righetti, 1987) showed that southernmost Switzerland was exposed to tremendous amounts of acid wet and dry deposition. Further inquests about the population statuses of the alpine lakes at the local Fishery and Game Department revealed that it was not known whether there were any fish left in these lakes, and that despite periodical stocking of these lakes with fish, no fish had been caught recently. Thus it was of interest to analyse the water of some of these lakes and to try to assess their fish population statuses. As the periodical stocking of these lakes proved unsuccessful, even though these lakes had a history of containing healthy fish populations, the question was raised whether the water conditions of these lakes are such that they wouldn't allow successful stocking. In order to answer this question one lake, Lake Laiozza, was chosen for a stocking experiment. 


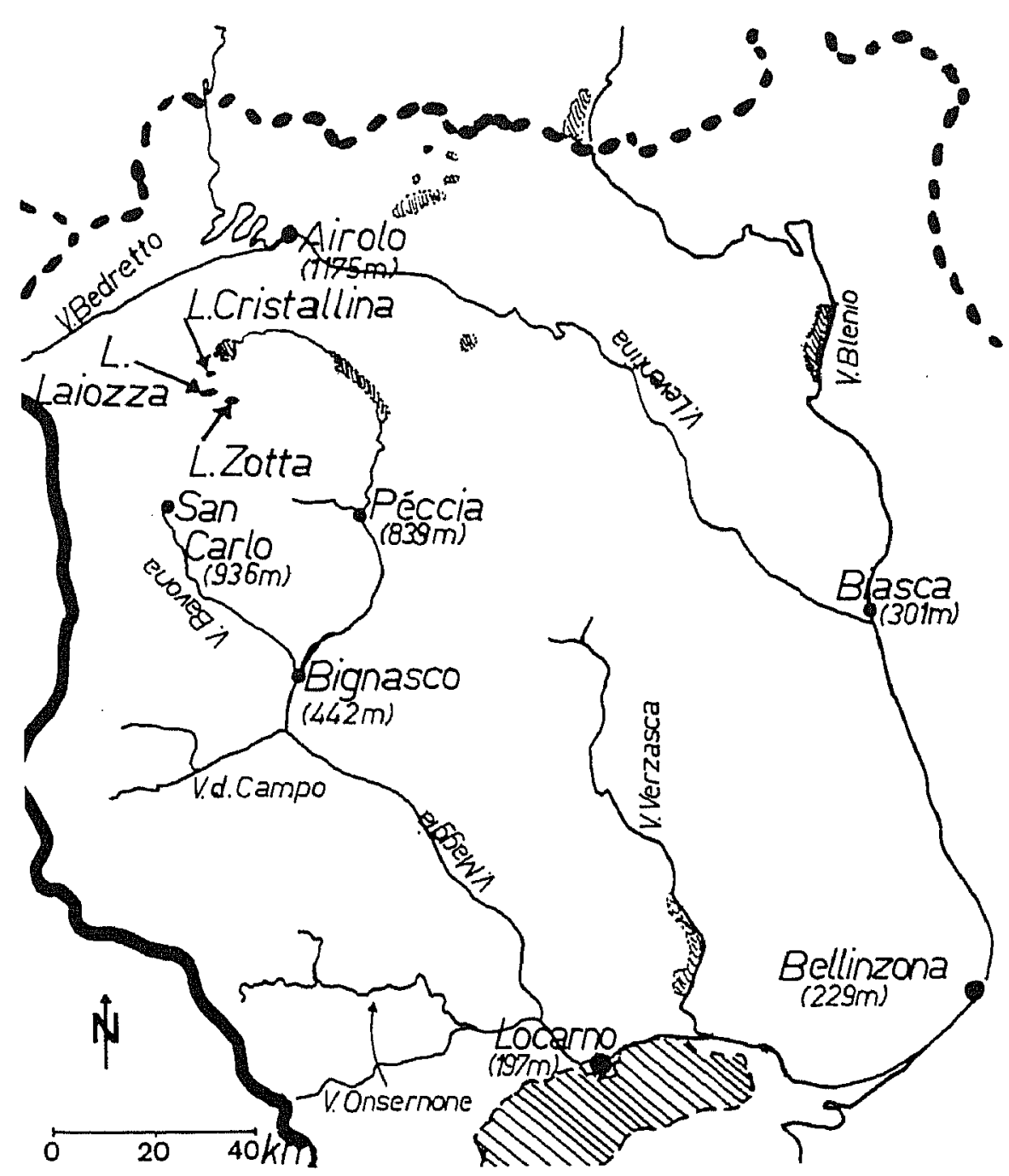

Figure 2. Enlarged map of the Canton Ticino and the experimental area. Numbers within the brackets denote meters above sea level.

\section{Materials and Methods}

\section{Location of the lakes and investigation procedures}

Three lakes, Lake Cristallina, Lake Laiozza, and Lake Zotta, located on the southern outcrops of the Cristallina Massive in the south of Switzerland (figures 1 and 2) were chosen for this investigation because of their accessibility. The geology in the respective area is a non-calcerous, crystalline bedrock, consisting mainly of gneisses and granites (Zobrist et al., 1986). Due to the high elevation (table 1) only a sparse vegetation, in form of a very thin layer of soil, overgrown with herbs, grasses, lichen, and mosses is present in the vicinity of these lakes.

Water samples were taken repeatedly as soon as the ice on the lakes had thawed to enable sampling i.e. starting on July 16, 1987 and repeated on July 21, July 29, August 6, August 20, and August 22. The water was collected in prewashed $1 \mathrm{~L}$ polyethylene bottles, the bottles were put into a cooler at $4^{\circ} \mathrm{C}$ and transported to the laboratory for analysis. The time between sampling and analysis did not exceed 24 
Table 1. Characterization of three alpine lakes located in southernmost Switzerland (from Righetti, 1981).

\begin{tabular}{lcccc}
\hline Lake & $\begin{array}{c}\text { Size } \\
{[\mathrm{ha}]}\end{array}$ & $\begin{array}{c}\text { approx. Depth } \\
{[\mathrm{m}]}\end{array}$ & $\mathrm{pH}$ & $\begin{array}{c}\text { Altitude } \\
{[\mathrm{m} . \mathrm{a} . \mathrm{sl} .]}\end{array}$ \\
\hline Cristallina & 1.25 & $4-6$ & 5.40 & 2389 \\
Laiozza & 1.68 & $6-7$ & 5.50 & 2365 \\
Zotta & 1.65 & $6-8$ & 5.05 & 2229 \\
\hline
\end{tabular}

hours. The analysis was carried out in accordance with the Swiss Federal Guidelines for Water Analysis (1983). Starting July 16, 1987 gill nets of varying mesh width were set in each lake in order to assess the respective fish population statuses.

Fish that were caught in the gill nets were anaesthetized with $100 \mathrm{mg} / \mathrm{L} \mathrm{MS}-222$ (Sandoz AG, Basel, Switzerland), blood sampled, and dissected. Hematocrit, plasma $\mathrm{Na}$, plasma $\mathrm{Cl}$, and plasma $\mathrm{Al}$ were determined from these samples. Gill, liver, and kidney samples were taken for histopathology and for tissue aluminium analysis.

\section{Blood samples}

Blood was taken from the anaesthetized fish on site by puncturing the heart (Lehmann and Stürenberg, 1980) with a heparinized hypodermic needle (Li-Heparin, Terumo-Luer $\left.18 \mathrm{G} \times 1 \frac{1}{2^{\prime \prime}}\right)$ and letting the blood run into a $2 \mathrm{ml}$ heparinized polystyrol tube (Milian AG, Geneva, Switzerland). The blood samples were stored at $4^{\circ} \mathrm{C}$ until further processing.

\section{Hematocrit}

Microhematocrit capillaries (Capilet-C, American Dade, USA) were filled to the mark with wholeblood samples and sealed on both ends with tube sealer. The capillaries were then placed into a hematocrit-fuge (Readacrit, Clay Adams, USA) and centrifuged for five minutes. Hematocrit values were determined by laying the capillaries onto a microhematocrit scale $(0-100 \%$ in $1 \%$ units, Heraeus Co., FRG).

\section{Plasma Na and Cl analysis}

Plasma Na was analysed on a Corning 435 flamephotometer (Corning Ltd., UK), having a detection limit of $1 \mathrm{mM} \mathrm{Na} / \mathrm{L}$. The flamephotometer was calibrated using Corning $140 \mathrm{mM} \mathrm{Na} / \mathrm{L}$ standard.

All plasma $\mathrm{Cl}$ analyses were done at the Childrens Hospital in Zürich using coulometric titration on an Analyzer 92 (Corning Ltd, UK), calibrated with aqueous chloride standards, and a detection range of $10-150 \mathrm{mM} \mathrm{Cl} / \mathrm{L}$. 


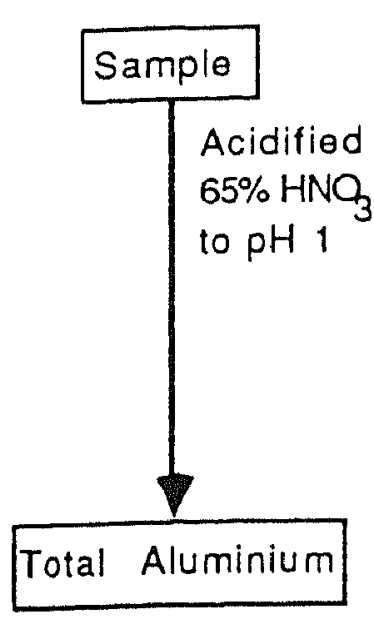

A

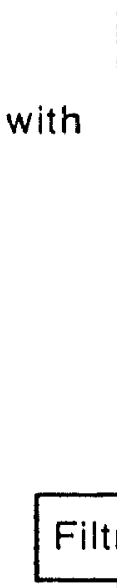

B
Sample

Filtration $0.22 \mu \mathrm{m}$ Millipore Filter

Suspended Aluminium

E

Aluminium

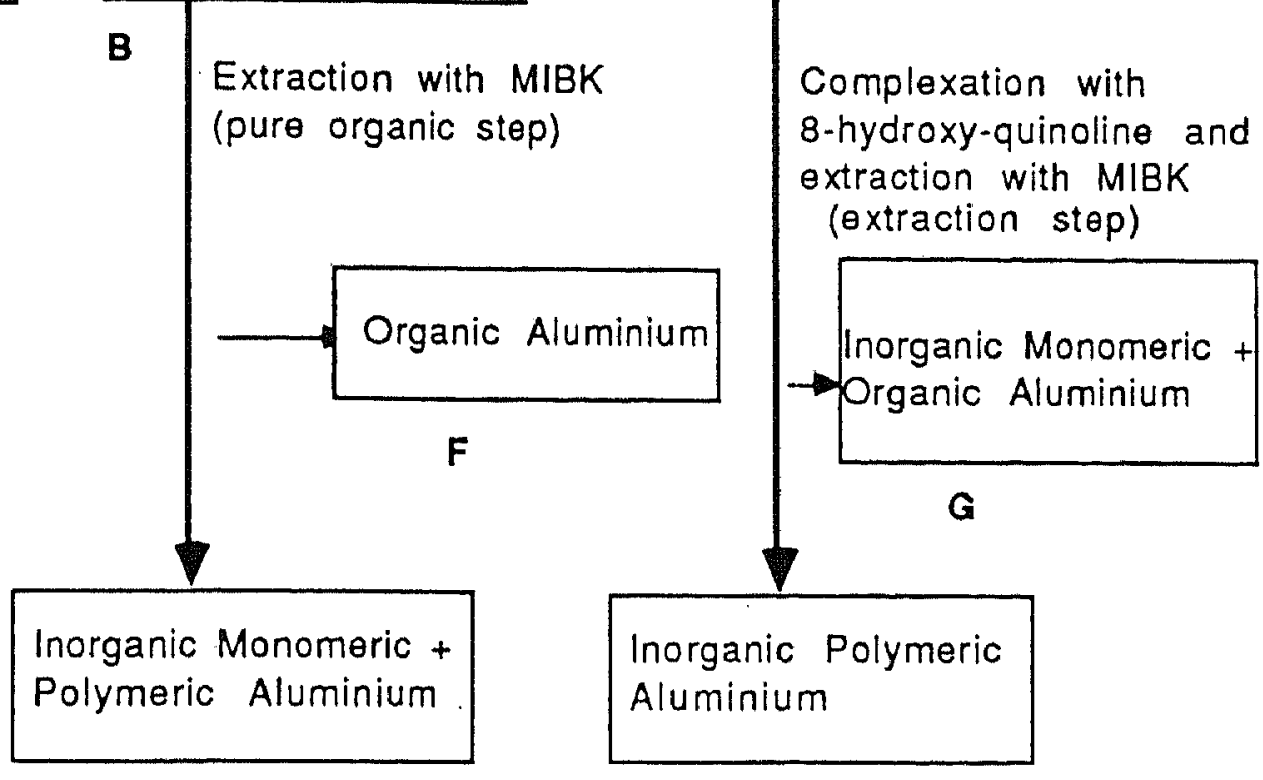

C

D

Figure 3. Schematic diagram of the water aluminium fractionation method used.

\section{Histopathology}

Gill (2nd gill arch, left side, direction "tail-head"), kidney (middle section), and liver samples were taken and put immediately into $4 \%$ buffered $\left(\mathrm{pH} 6.5-6.8, \mathrm{CaCO}_{3}\right)$ formaldehyde solution. These samples were then dehydrated in an increasing series of ethanol i. e. $70 \%, 95 \%$, and $100 \%$, embedded in paraffin, and cut into $5 \mu \mathrm{m}$ thin slices. After gently placing the tissue slices onto a microscope glass-slide, they were deparaffinized for 15 minutes in xylene, stained with hematoxylin-eosin, and inspected under the microscope.

\section{Aluminium fractionation}

Aluminium fractionation was carried out on $100 \mathrm{ml}$ lake water samples collected in acid $\left(\mathrm{HNO}_{3}\right)$ washed polyethylene bottles within two hours after taking the samples. 
Table 2. Temperature program used for $\mathrm{Al}$ analysis.

\begin{tabular}{lccc}
\hline Steps & Temp. $\left({ }^{\circ} \mathrm{C}\right)$ & Ramp (sec.) & Hold (sec.) \\
\hline Drying & 110 & 10 & 15 \\
Ashing & 1450 & 10 & 10 \\
Cooling & 20 & 1 & 2 \\
Atomizing & 2200 & 0 & 5 \\
Cleaning & 2500 & 1 & 3 \\
\hline
\end{tabular}

The fractionation technique used was basically the same as described by Barnes (1975) and later modified by LaZerte (1984) though no dialysis or cation exchange resin steps were carried out but an extra MIBK extraction step introduced in turn (figure 3).

Of the fractions $A-G$ only the fractions A-D were analysed. Fractions $E, F$ and $G$ were calculated by substractions e. $\mathrm{g}$. $\mathrm{A}-\mathrm{B}=\mathrm{E}$. The labile aluminium concentrations are identical with the inorganic monomeric fraction and thus can be calculated $(\mathrm{C}-\mathrm{D}$ or $\mathrm{G}-\mathrm{F}=$ labile aluminium $)$. All fractions were acidified with $65 \%$ quartzdistilled $\mathrm{HNO}_{3}$ to an approx. $\mathrm{pH}$ of 3 prior to analysis.

\section{Tissue aluminium}

To bring the different tissues into a form in which aluminium could be analysed, they were acid digested according to the method of Stoeppler and Backhaus (1978). Details of this acid digestion procedure can be found in Dietrich (1988).

\section{Aluminium analysis}

The analyses of the plasma and tissue samples as well as the different Al-fractions were done by electrothermal atomic absorption spectrometry (ETAAS) on a Perkin-Elmer model consisting of a HGA 500 graphite furnace, a model $5000 \mathrm{spec}-$ trophotometer, and an AS-1 autosampler. All samples were calibrated using the method of standard additions. More detailed information as to this method and the detection limits of ETAAS are given by Rickenbacher (1984), Känzig et al. (1987), and Dietrich (1988). Each water sample was injected into the ETAAS four times. The standard deviation of these repetitive analyses was $\pm 5 \mu \mathrm{g} \mathrm{Al} / \mathrm{L}$. For all sample types one temperature program was used (table 2 ). The usual procedure was to mix $100 \mu \mathrm{l}$ of sample diluent $\left(0.25 \%\right.$ Triton X-100 in doubly distilled $\left.\mathrm{H}_{2} \mathrm{O}\right), 50 \mu \mathrm{l}$ of sample, and $50 \mu$ l of aluminium standard within the ETAAS sample cups. The standards 0,50 , and $100 \mathrm{ppb} \mathrm{Al}$ were made up from a $1000 \mu \mathrm{g} \mathrm{Al} / \mathrm{L}$ solution (Fixanal, Riedelde-Häen AG, Hannover, FRG) and acidified with quartz distilled $\mathrm{HNO}_{3}$ to $\mathrm{pH} 3$. The quality of the aluminium analysis by ETAAS was controlled by participating in a monthly round-robin "Trace Element Assessment Scheme" (Trace Element Reference Center, Guildford, UK) analyzing aluminium in water, dialysis fluids, and sera. 


\section{Stocking experiment}

160 one year old and 160 two years old brown trout (Salmo trutta fario) were purchased from the Cantonal Fish Hatchery in Golino, close to the experimental area. All fish were inspected for health previous to the transport. The transport, on September 3, 1987, to the remote Lake Laiozza was carried out by helicopter (HeliTicino SA). At the lake all fish were removed from the fiberglass containers and put directly into a keep-net $\left(8 \mathrm{~m}^{3}\right.$ polyethylene net with $4 \mathrm{~mm}$ meshwidth) in the lake. The temperature difference between the container water and the lake water did not exceed $1^{\circ} \mathrm{C}$. The water temperature of Lake Laiozza was $11^{\circ} \mathrm{C}$.

\section{Experimental procedure}

The keep-net was inspected every day for dead fish or fish having lost their equilibrium (immobilized). The dead fish were removed, counted, and categorized. The immobilized fish were removed, counted, categorized, anaesthetized, and then processed as described above with the exception that no liver and kidney samples were taken for histopathology and tissue aluminium analysis.

Water samples were taken one day previous to stocking the brown trout in Lake Laiozza (September 2) and then on every day of the experiment. The procedure of sampling and analysis was the same as used in the investigation of the three lakes Laiozza, Cristallina and Zotta, and are described above.

\section{Results}

\section{Water analyses}

The comparison of the water $\mathrm{pH}$ 's measured in 1981 (table 1) with those recorded in summer 1987 (table 3), gives no clear evidence of an increased acidification of the respective lake waters. The $\mathrm{pH}$ values measured in 1981 by Righetti represent one $\mathrm{pH}$ measurement per lake only and thus clearly do not relate a clear picture of the lake pH's of these lakes in 1981. Due to the lack of better data these values have been used for comparison with the values obtained in our study. Lacking measurements of aqueous buffering capacity in the previous study as well as in ours furthermore prevent drawing any conclusions to the effects of acidification on these lakes. The waters of all three lakes are ex tremely soft, i. e. their typical features are low conductivity and a very low ion content. The low ion content reflects a condition unique for high elevation alpine lakes. As the area surrounding the lakes is covered only with an extremely thin layer of soil, lacking trees or bushes, the water in these lakes is considered as being essentially "rainwater" enriched with ions having been leached from the bedrock and the little soil there is (Barbieri and Righetti, 1987). The same holds true for the aluminium found in these lakes. These concentrations are resultants of the dissolution reactions of the crystalline bedrock of the area with the acid deposited (Zobrist et al., 1986, Johnson, 1984), a situation which stands in contrast to the 
Table 3. Water compositions of Lake Cristallina, Lake Laiozza, and Lake Zotta as analysed in summer 1987. Values denote arithmetic means \pm standard deviation.

\begin{tabular}{lccr}
\hline Parameters & Lake Cristallina & Lake Laiozza & Lake Zotta \\
\hline $\mathrm{pH}$ & $5.02 \pm 0.37$ & $5.37 \pm 0.22$ & $4.84 \pm 0.09$ \\
Temperature $\left[{ }^{\circ} \mathrm{C}\right]$ & $7.6 \pm 4.4$ & $9.7 \pm 4.0$ & $9.1 \pm 2.6$ \\
Conductivity $[\mu \mathrm{S} / \mathrm{cm}]$ & $8.7 \pm 2.6$ & $7.5 \pm 1.2$ & $10.9 \pm 1.5$ \\
$\mathrm{O}_{2}[\mathrm{mg} / \mathrm{L}]$ & $9.6 \pm 0.8$ & $8.8 \pm 0.7$ & $9.5 \pm 0.6$ \\
Total Al $[\mu \mathrm{g} \mathrm{Al} / \mathrm{L}]$ & $99 \pm 22$ & $92 \pm 21$ & $168 \pm 19$ \\
$\mathrm{Labile} \mathrm{Al}[\mu \mathrm{g} \mathrm{Al} / \mathrm{L}]$ & $65 \pm 22$ & $56 \pm 25$ & $116 \pm 27$ \\
$\mathrm{Susp} . \mathrm{Al}[\mu \mathrm{g} \mathrm{Al} / \mathrm{L}]$ & $33 \pm 18$ & $38 \pm 17$ & $36 \pm 16$ \\
$\mathrm{Ca}^{2+}[\mu \mathrm{g} / \mathrm{L}]$ & $511 \pm 86$ & $535 \pm 15$ & $475 \pm 30$ \\
$\mathrm{Mg}^{2+}[\mu \mathrm{g} / \mathrm{L}]$ & $41 \pm 23$ & $32 \pm 11$ & $35 \pm 26$ \\
$\mathrm{Na}^{+}[\mu \mathrm{g} / \mathrm{L}]$ & $123 \pm 39$ & $115 \pm 27$ & $96 \pm 25$ \\
$\mathrm{~K}^{+}[\mu \mathrm{g} / \mathrm{L}]$ & $122 \pm 24$ & $129 \pm 11$ & $155 \pm 22$ \\
$\mathrm{Si}^{[}[\mu \mathrm{g} / \mathrm{L}]$ & $303 \pm 80$ & $333 \pm 54$ & $253 \pm 45$ \\
$\mathrm{NH}_{4}^{+}[\mu \mathrm{g} / \mathrm{L}]$ & $32 \pm 23$ & $17 \pm 15$ & $27 \pm 14$ \\
$\mathrm{NO}_{3}^{-}[\mu \mathrm{g} / \mathrm{L}]$ & $227 \pm 15$ & $127 \pm 35$ & $308 \pm 18$ \\
$\mathrm{Cl}^{-}[\mu \mathrm{g} / \mathrm{L}]$ & $58 \pm 63$ & $28 \pm 37$ & $43 \pm 21$ \\
$\mathrm{SO}_{4}^{2-}[\mu \mathrm{g} / \mathrm{L}]$ & $1517 \pm 41$ & $1677 \pm 25$ & $1793 \pm 93$ \\
\hline
\end{tabular}

Table 4. Water composition of Lake Laiozza one day before, September 2, 1987, and during the stocking experiment, September 3-7, 1987.

\begin{tabular}{lcccccc}
\hline Parameters & 2.9 .87 & 3.9 .87 & 4.9 .87 & 5.9 .87 & 6.9 .87 & 7.9 .87 \\
\hline Temp. $\left[{ }^{\circ} \mathrm{C}\right]$ & 10.5 & 11.0 & 11.0 & 10.5 & 9.0 & 8.5 \\
$\mathrm{pH}$ & 5.55 & 5.36 & 5.08 & 5.42 & 5.34 & 5.70 \\
$\mathrm{Cond} .[\mu \mathrm{S} / \mathrm{cm}]$ & 7.8 & 7.4 & 7.1 & 7.9 & 7.7 & 7.7 \\
$\mathrm{O}_{2}[\mathrm{mg} / \mathrm{L}]$ & 8.3 & 8.3 & 8.3 & 8.5 & 8.5 & 8.5 \\
Total-Al $[\mu \mathrm{g} / \mathrm{L}]$ & 139 & 139 & 75 & 119 & 102 & 151 \\
$\mathrm{Labile}-\mathrm{Al}[\mu \mathrm{g} / \mathrm{L}]$ & 46 & 41 & 46 & 44 & 41 & 52 \\
$\mathrm{Susp}-\mathrm{Al}[\mu \mathrm{g} / \mathrm{L}]$ & 79 & 96 & 29 & 75 & 61 & 99 \\
$\mathrm{Ca}^{2+}[\mu \mathrm{g} / \mathrm{L}]$ & 545 & 534 & 483 & 485 & 496 & 523 \\
$\mathrm{Mg}^{2+}[\mu \mathrm{g} / \mathrm{L}]$ & 10 & 10 & 12 & 13 & 25 & 35 \\
$\mathrm{Na}^{+}[\mu \mathrm{g} / \mathrm{L}]$ & 146 & 109 & 123 & 150 & 132 & 121 \\
$\mathrm{~K}^{+}[\mu \mathrm{g} / \mathrm{L}]$ & 150 & 118 & 131 & 151 & 128 & 128 \\
$\mathrm{NH}_{4}^{+}[\mu \mathrm{g} / \mathrm{L}]$ & 10 & 10 & 10 & 20 & 20 & 10 \\
$\mathrm{Si}^{{ }^{+}}[\mu \mathrm{g} / \mathrm{L}]$ & 360 & 370 & 370 & 390 & 400 & 400 \\
$\mathrm{SO}_{4}^{2-}[\mu \mathrm{g} / \mathrm{L}]$ & 1693 & 1693 & 1564 & 1636 & 1628 & 1639 \\
$\mathrm{NO}_{3}^{-}[\mu \mathrm{g} / \mathrm{L}]$ & 140 & 110 & 110 & 120 & 120 & 130 \\
$\mathrm{Cl}^{-}[\mu \mathrm{g} / \mathrm{L}]$ & 46 & 0 & 17 & 21 & 0 & 51 \\
\hline
\end{tabular}

general scenario of aluminium and minerals being leached from tree covered podzol soils (Cronan and Schofield, 1979, Johnson et al., 1981) as is generally the case in North America, Sweden, and Norway.

The water $\mathrm{pH}$ values right before and during the stocking experiment in Lake Laiozza varied considerably from day to day (figure 4). The fluctuations of the $\mathrm{pH}$ and total Al concentrations (table 4) seemed to have been induced by a change of the water renewal within the lake, which in turn was influenced by meteorological events. Indeed, varying lake water volumes were recorded by visually controlling the 


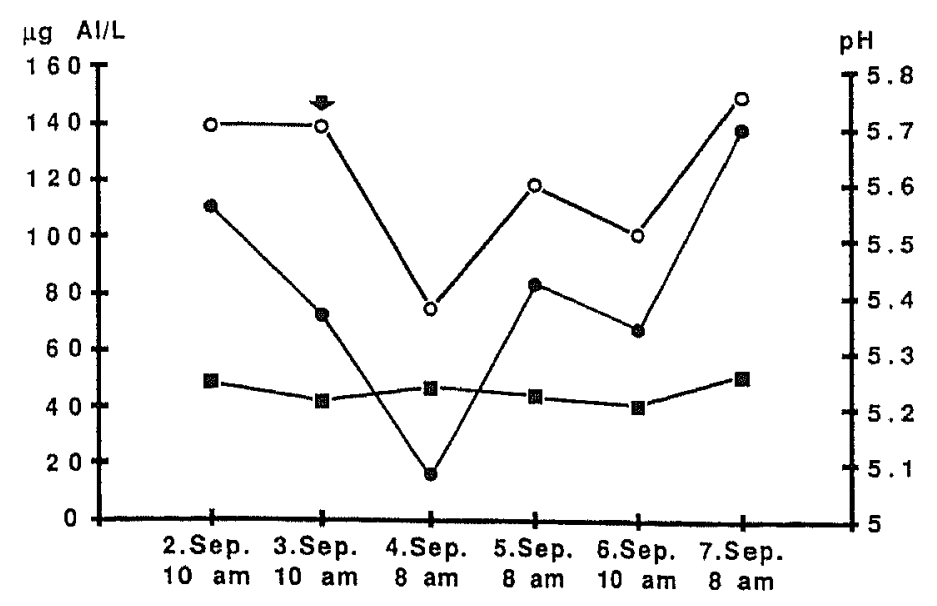

Figure 4. $\mathrm{pH}$ values and aluminium fractions measured in Lake Laiozza during the stocking experiment in fall 1987. denotes $\mathrm{pH}, \mathrm{O}$ total-Al, labile-Al, and indicates the beginning of the stocking experiment. Suspended $\mathrm{Al}=$ total-labile $\mathrm{Al}$.

water depth at the lake outflow, thus giving testimony of the effects of increased snow melting. Beside being influenced by the water renewal, the daily $\mathrm{pH}$ fluctuations may also represent a very low aqueous buffering capacity (Discroll, 1989).

\section{Fishery status}

There were no fish present in the lakes Zotta and Cristallina. One approximately 5 years old brook trout (Salvelinus fontinalis) was caught in Lake Laiozza. This fish had a high hematocrit, moderately low levels of plasma electrolytes, a high plasma aluminium concentration, and high gill, liver, and kidney aluminium concentrations (table 5).

\section{Mortality and symptoms during the stocking experiment}

The water of Lake Laiozza was acutely lethal to the brown trout stocked. The mortality being practically the same for one and two years old fish exposed (figure 5).

Table 5. Hematocrit, blood plasma constituents, and organ aluminium concentrations of the brook trout caught in Lake Laiozza in summer 1987. The values of the organ aluminium concentrations are means \pm standard deviations of triple acid tissue digestions and subsequent analyses.

\begin{tabular}{lc}
\hline Parameters & Brook trout (Salvelinus fontinalis) \\
\hline Hematocrit $(\%)$ & 77 \\
Plasma Na $(\mathrm{meq} / \mathrm{L})$ & 131 \\
Plasma Cl $(\mathrm{meq} / \mathrm{L})$ & 116 \\
Plasma K $(\mathrm{meq} / \mathrm{L})$ & 1.6 \\
Plasma Al $(\mathrm{ng} / \mathrm{ml})$ & 170 \\
Gill Al $(\mu \mathrm{g} / \mathrm{g})$ & $126.9 \pm 3.3$ \\
Liver Al $(\mu / \mathrm{g})$ & $30.5 \pm 6.3$ \\
Kidney Al $(\mu \mathrm{g} / \mathrm{g})$ & $12.9 \pm 0.1$ \\
\hline
\end{tabular}




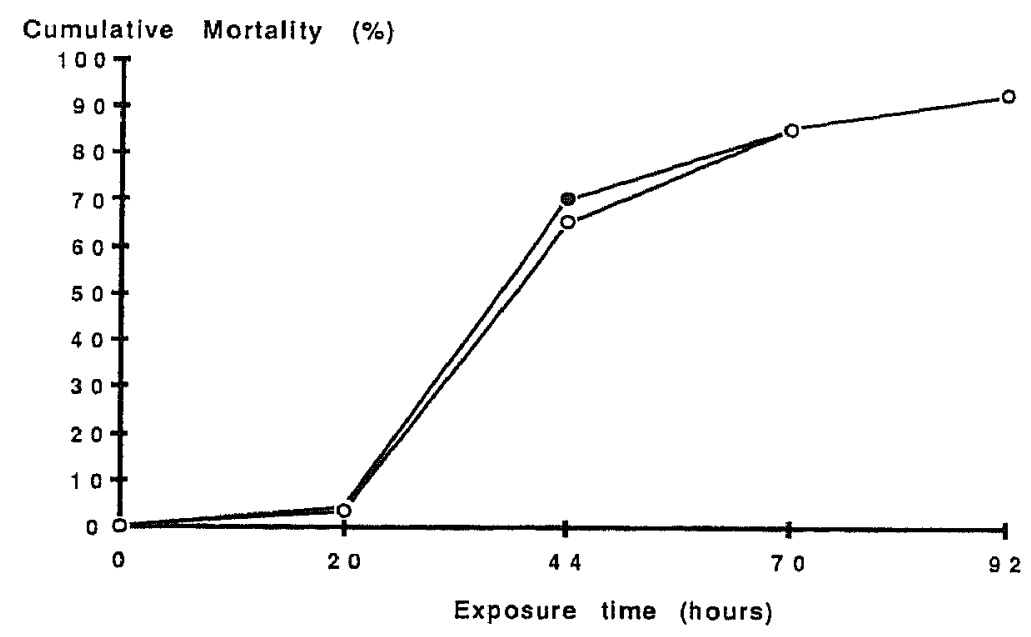

Figure 5. Cumulative mortality of one and two years old brown trout stocked in Lake Laiozza in September 1987. denotes one year old fish and $\bigcirc$ two years old fish.

The symptoms before death observed were thrashing, heavy breathing, little gaping, sometimes coughing (flow reversal), laying immobilized on the bottom of the keepnet, and eventually loss of equilibrium. These symptoms correspond closely to the symptoms recorded when we exposed rainbow trout (Salmo gairdneri, R.) to $400 \mu \mathrm{g} \mathrm{Al} / \mathrm{L}$ at pH 5.4 in the somewhat harder EPA medium (Dietrich and Schlatter, 1989).

\section{Hematocrit and plasma parameters}

All hematocrit values were extremely high when compared to the $41 \pm 4 \%$ found in brown trout sampled at the hatchery (Dietrich, 1988).

Fish dying after 72 hours did not have higher hematocrits than fish that died after 24 hours.

All dying fish were depleted of plasma chloride and plasma sodium (table 6). These plasma electrolyte concentrations compare well to the levels observed in fish killed in acidified streams (Leivestad et al., 1980, Muniz and Leivestad, 1980 a, Skogheim et al., 1984).

The plasma Al concentrations (PAC) were elevated in all sample groups. These values are decidedly higher than the $10 \pm 8 \mathrm{ng} \mathrm{Al} / \mathrm{ml}$ found in brown trout raised on an aluminium contaminated trout chow at the fish hatchery (Dietrich, 1988), and thus suggests that aluminium had been taken up during the exposure.

\section{Gill aluminium}

Substantial concentrations of aluminium were measurable in all gills (table 7). An increase of gill $\mathrm{Al}$ was observed for both age groups after September 5 . This increase seemed to coincide with a raise in suspended $\mathrm{Al}$ concentration in the water (table 7 and figure 4) but may also be interpreted as an effect of the longer exposure time. 
Table 6. Hematocrit and plasma parameters of one and two years old brown trout stocked in Lake Laiozza in September 1987. Values denote the arithmetic means \pm standard deviations of sample groups and of all samples within an age group. [] denote the number of samples analyzed within a group.

\begin{tabular}{|c|c|c|c|c|c|}
\hline $\begin{array}{c}\text { Age } \\
\text { [years] }\end{array}$ & $\begin{array}{l}\text { Sampling } \\
\text { Date }\end{array}$ & $\begin{array}{c}\text { Hematocrit } \\
{[\%]}\end{array}$ & $\begin{array}{c}\text { Plasma Na } \\
{[\mathrm{meq} / \mathrm{L}]}\end{array}$ & $\begin{array}{c}\text { Plasma Cl } \\
{[\mathrm{meq} / \mathrm{L}]}\end{array}$ & $\begin{array}{c}\text { Plasma Al } \\
{[\mu \mathrm{g} / \mathrm{L}]}\end{array}$ \\
\hline 1 & 4.9 .87 & $62 \pm 5[6]$ & $109 \pm 8[4]$ & $67 \pm 9[6]$ & $68 \pm 21[6]$ \\
\hline 1 & 5.9 .87 & $67 \pm 5[9]$ & $102 \pm 7[6]$ & $60 \pm 9[8]$ & $58 \pm 11[9]$ \\
\hline 1 & 6.9 .87 & $64 \pm 5[3]$ & 93 [1] & $63 \pm 9[2]$ & $47 \quad[1]$ \\
\hline 1 & 7.9. 87 & $73 \pm 6[16]$ & $104 \pm 14[9]$ & $65 \pm 11[11]$ & $62 \pm 21[15]$ \\
\hline 1 & $x$ all & $69 \pm 7[34]$ & $104 \pm 11[19]$ & $64 \pm 9[27]$ & $61 \pm 18[30]$ \\
\hline 2 & 4.9 .87 & $58 \pm 6[5]$ & $106 \pm 5[5]$ & $70 \pm 4[5]$ & $129 \pm 72[5]$ \\
\hline 2 & 5.9 .87 & $65 \pm 9[7]$ & $102 \pm 12[6]$ & $69 \pm 7[7]$ & $56 \pm 28[7]$ \\
\hline 2 & 6.9 .87 & $66 \pm 7[4]$ & $95 \pm 7[4]$ & $65 \pm 7[4]$ & $40 \pm 23[4]$ \\
\hline 2 & 7.9 .87 & $71 \pm 6[14]$ & $101 \pm 9[11]$ & $67 \pm 6[14]$ & $41 \pm 14$ [12] \\
\hline 2 & $\mathrm{x}$ all & $67 \pm 8[30]$ & $101 \pm 9[26]$ & $67 \pm 7[30]$ & $60 \pm 48[28]$ \\
\hline
\end{tabular}

Table 7. Suspended Al fraction concentrations in the lakewater of Lake Laiozza and mean gill aluminium concentrations of sample and age groups at the respective sample dates. Values are arithmetic means \pm standard deviations. [] denote the number of gill samples analyzed.

\begin{tabular}{cccc}
\hline $\begin{array}{c}\text { Age } \\
\text { [years] }\end{array}$ & $\begin{array}{c}\text { Sampling } \\
\text { Date }\end{array}$ & $\begin{array}{c}\text { Suspended-Al } \\
{[\mu \mathrm{g} \mathrm{Al} / \mathrm{L}]}\end{array}$ & $\begin{array}{c}\text { Gill-Al } \\
{[\mu / \mathrm{g} \text { wet weight] }}\end{array}$ \\
\hline 1 & 4.9 .87 & 29 & $124.7 \pm 49.2[7]$ \\
1 & 5.9 .87 & 75 & $243.0 \pm 11.8[10]$ \\
1 & 6.9 .87 & 61 & $426.0 \pm 71.5[3]$ \\
1 & 7.9 .87 & 99 & $367.3 \pm 139.0[15]$ \\
2 & & & \\
2 & 4.9 .87 & 75 & $227.0 \pm 66.9[8]$ \\
2 & 5.9 .87 & 61 & $168.9 \pm 42.9[4]$ \\
2 & 6.9 .87 & 99 & $210.2 \pm 57.2[14]$ \\
\hline
\end{tabular}

\section{Gill histopathology}

A high degree of gill damage was observable in all gills inspected. This damage consisted mainly of epithelial lifting, fusion of secondary lamellae, necrosis, hyperplasia, and mucification. While little mucification was seen in the gills of the fish that were sampled on the morning of September 4, mucous clogging was prevalent in the most gills of fish sampled 24 hours later and thereafter. The gill lesions observed and mentioned above are shown in a composite diagram in figure 6. 


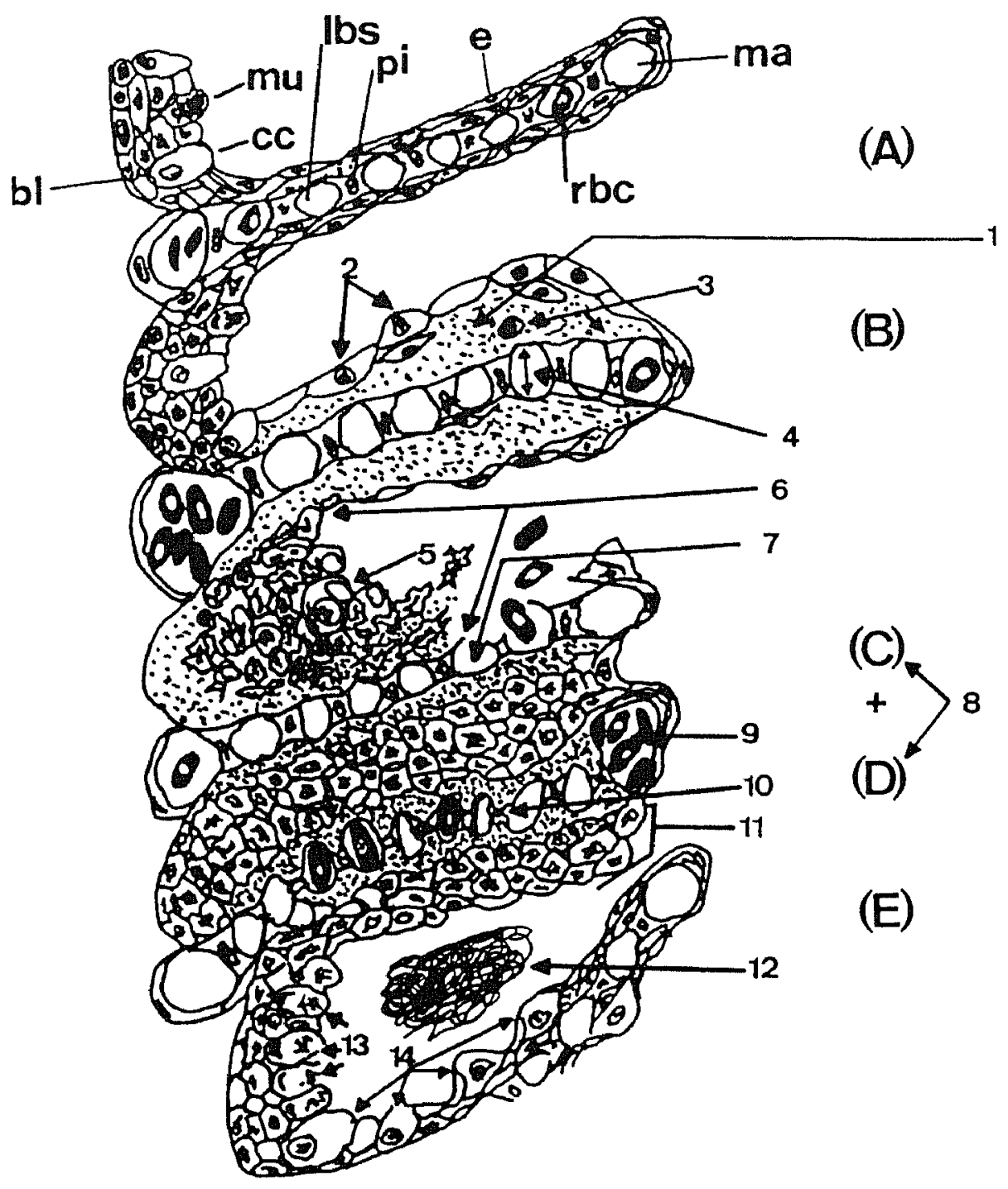

Figure 6. Composite diagram of the irritant-induced gill lesions. Five respiratory lamellae are shown (A-E), the top one of which is normal (Salmo gairdneri, modified from Mallatt, 1985). 1, epithelial lifting; 2, hypertrophy; 3 , edema and leucocyte infiltration of epithelium; 4, dilation of lamellar blood sinus; 5 , chloride cell damage; 6 , necrosis; 7 , epithelial rupture and bleeding into pharynx; 8 , lamellar fusion $(C+D)$; 9 , vascular congestion; 10 , constriction of lamellar blood sinus; 11 , hyperplasia i. e. epithelial cell proliferation; 12 , mucous secretion; 13 , mucous cell proliferation; 14, chloride cell proliferation. Abbreviations: bl, basal lamina; cc, chloride cell; e, typical lamellar epithelial cells; lbs, lamellar blood sinus; ma, marginal blood channel; mu, mucous cell; pi, pillar cell; rbc, red blood cell or erythrocyte.

\section{Discussion}

\section{Water parameters}

All three alpine lakes investigated had extremely low ion concentrations, low pH's, and elevated aluminium concentrations. While the low pH's can be explained as being a result of the wet and dry acid deposition (Barbieri and Righetti, 1987), the low ion concentrations and the elevated aluminium concentrations, are resultants of the genuine geological situation and various weathering reactions (Johnson, 1984) and also of slow dissolution reactions of the incoming acid with the bedrock (Zobrist 
et al., 1986). The comparison of the ion contents of the Swiss alpine lakes $(0.5 \mathrm{mg}$ $\mathrm{Ca} / \mathrm{L}, 0.11 \mathrm{mg} \mathrm{Na} / \mathrm{L}$ ) with the contents found in Scandinavian surface waters $(1.0 \mathrm{mg}$ $\mathrm{Ca} / \mathrm{L}, 3.2 \mathrm{mg} \mathrm{Na} / \mathrm{L}$ (Drablos and Tollan, 1980)) shows that the Swiss alpine lakes are extremely low in ion concentrations. This may be in part due to the circumstance that most of these lakes are rather small and thus have very short lake water residual times (Zobrist et al., 1986). A short residual time will counteract any concentrations of ions in the water, i. e. dilute the lake water due to the fact that i.) the incoming water is essentially "rainwater" (Barbieri and Righetti, 1987) and ii.) the dissolution reactions with the bedrock are very slow and thus cannot counteract the "ion loss" resulting from the dilution of the lake water and subsequent drainage of excess water into the receiving streams. These yet theoretical deductions are corroborated at least in part by the $\mathrm{Al}$ and $\mathrm{pH}$ measurements during the stocking experiment (figure 4 and table 4). In figure 4 the labile $\mathrm{Al}$ concentration appears to be invariable with $\mathrm{pH}$ changes. This is not so. The labile Al concentration is a fraction of the total Al concentration measured. So for example on September 4 the labile Al concentration makes up $61.3 \%$ of the total $\mathrm{Al}$ concentration, the $\mathrm{pH}$ being 5.08 , while on the following day the labile $\mathrm{Al}$ concentration represents only $37 \%$ of the total Al concentration present at a $\mathrm{pH}$ of 5.42. The "loss" of $\mathrm{Al}$ from the water on September 4 is a resultant of extremely warm weather leading to an increased amount of melt water running into the lake and consequently to the dilution of the present total $\mathrm{Al}$ concentration. The lower $\mathrm{pH}$ favored the forming of labile $\mathrm{Al}$ species, having a higher solubility at low $\mathrm{pH}$ (Burrows, 1977), and thus, as mentioned above, resulted in a higher labile $\mathrm{Al}$ concentration. In general the recorded $\mathrm{Al}$ concentrations are low in comparison to the values $(>250 \mu \mathrm{g} \mathrm{Al} / \mathrm{L})$ reported from Scandinavia. As suggested earlier this may well be a result of the unique geology and topography of the lakes investigated, meaning that aluminium is being leached more effectively from podzol soils (Scandinavia) than from crystalline bedrock (Switzerland). The low ion content can also be seen as a resultant of the low leaching efficacy in this area. The high $\mathrm{Na}$ and $\mathrm{Cl}$ concentrations in the Scandinavian waters, on the other hand, besides being leached from podzol-soils, are resultants of the seaspray from the Atlantic Ocean. Indeed, Wright and Snekvik (1978), found higher $\mathrm{Na}$ and $\mathrm{Cl}$ concentrations in lakes situated close to the coast than in lakes laying farther inland.

\section{Mortality and symptoms}

The lack of fish in the lakes Cristallina and Zotta as well as the marginal presence of fish in Lake Laiozza suggests that these lake waters are detrimental to fish populations. The high aluminium concentrations measured in the plasma, gills, liver, and kidney of the brook trout caught in Lake Laiozza indicate that aluminium may have contributed to the disappearance of the fish in these lakes.

The results of the stocking experiment show that the water of Lake Laiozza is acutely toxic to brown trout, irrespective of the age of the brown trout stocked. Bearing in mind that a $\mathrm{pH}$ of 5.4 is considered as being not toxic to fish (Daye and Garside, 1975) and that brown trout have been found living in the chronically acid Tovdal river with a similarly ion deprived water as found in Lake Laiozza (Muniz and Lei- 
vestad, $1980 \mathrm{a}$ ), it seems unlikely that the low $\mathrm{pH}$ in combination with the ion deprived water of Lake Laiozza induced the observed toxicity.

The symptoms of intoxication observed, the low plasma electrolyte concentrations measured, as well as the histopathological changes seen in the gills of the fish of the stocking experiment resembled the symptoms described for fish acutely intoxicated with high concentrations of aluminium (Dietrich, 1988, Dietrich and Schlatter, 1989, Fivelstad and Leivestad, 1984, Skogheim and Rosseland, 1986, Muniz and Leivestad, 1980 b) so closely, that aluminium and not unspecific stress reactions resulting from the transport, seemed most likely to be the factor responsible for the lethal effects. Other toxicants e. g. heavy metals can be ruled out as their concentrations were extremely low $(\mathrm{Hg}>1 \mu \mathrm{g} / \mathrm{L} ; \mathrm{Pb}>2 \mu \mathrm{g} / \mathrm{L}$, and $\mathrm{Cd}$ below detection limit of $0.1 \mu \mathrm{g} / \mathrm{L}$, all measured with electrothermal atomic absorption spectrometry).

Surprisingly Fivelstad and Leivestad (1984) as well as Skogheim and Rosseland (1986), who exposed atlantic salmon (Salmo salar L.) and brown trout (Salmo trutta f.) to a comparable $\mathrm{pH}$, aluminium concentration, and water as prevalent in Lake Laiozza for 26 days, did not observe mortality. A scrutinous comparison of the water composition in their experiments with the composition found in Lake Laiozza showed that their experimental waters contained significantly higher $\mathrm{Na}$ and $\mathrm{Cl}$ concentrations $(3.9 \mathrm{mg} \mathrm{Na} / \mathrm{L})$. As all other water components, including $\mathrm{Ca}$, were of comparable level, it is suggested that the higher $\mathrm{Na}$ and $\mathrm{Cl}$ concentration in Lake Liervatn and River Mulelven (Skogheim and Rosseland, 1986 and Fivelstad and Leivestad, 1984, respectively), could have had a mitigating effect regarding the toxicity of aluminium to salmonids. It has to be emphasized though that other complexing agents such as e. g. humic acids (Discroll et al., 1980, Baker and Schofield, 1982) or as indicated in the introduction Si (Birchall et al., 1989) may have mitigated Altoxicity in the Scandinavian experiments. Lack of data on the Si-concentrations present in the Scandinavian experiments, and the lack of humic acid measurements in our experiment prevented a comparison.

Evidence corroborating the mitigating effects of $\mathrm{Na}$ and $\mathrm{Cl}$ have already been brought forward by Brown (1981) and Hutchinson et al. (1987), though not for aluminium intoxications but for toxic effects at extremely low $\mathrm{pH}$. In consequence to the results obtained in this transplantation experiment, we carried out similar experiments in the laboratory with artificial Lake Laiozza water but varying $\mathrm{NaCl}$ concentrations (Dietrich et al., 1989). High $\mathrm{NaCl}$ concentrations did mitigate aluminium toxicity i. e. reduced the ion loss, as also previously encountered in the transplantation experiment, but could not mitigate the cytotoxicity of aluminium. Thus high $\mathrm{NaCl}$ concentrations prolonged survival, indicating that $\mathrm{Na}$ and $\mathrm{Cl}$ concentrations are important parameters influencing the toxicity of aluminium in acid water.

A further aspect concerning the discrepancy between this and the Scandinavian study that has to be considered is the existence of strain differences. While some Scandinavian brown trout strains may already have adjusted to lowered $\mathrm{pH}$ and slightly elevated aluminium conditions (Rosseland and Skogheim, 1987), the brown trout raised in Swiss hatcheries, using moderately hard and neutral water, have not. 


\section{Conclusion}

Lake Laiozza water is acutely toxic to brown trout irrespective of the age of the fish. The presence of one specimen of brook trout and the absence of the once indigeneous brown trout i) corroborates respective reports that brook trout are less susceptible to aluminium intoxication than any other salmonid species (Baker and Schofield, 1980, Rosseland and Skogheim, 1984, Wood and McDonald, 1987), and ii) indicates that even most resistant species, such as brook trout, are not able to survive in Lake Laiozza.

The symptoms before death, the measured electrolyte losses, the severe damage of the gill epithelia, and the mucification of the gills point to aluminium as being the intoxicating agent in the stocking experiment.

The apparent discrepancy between the predictions based on laboratory and literature data and the actual outcome of the stocking experiment indicates that parameters other than just $\mathrm{pH}$, aluminium concentration, $\mathrm{Ca}, \mathrm{Si}$, and humic acid concentration, such as e.g. the $\mathrm{Na}$ and $\mathrm{Cl}$ concentrations of the water, are of importance regarding the potential of aluminium toxicity to fish. Therefore, beside a careful analysis of the divers water parameters, a thorough search for the most suitable and least susceptible fish species and strain should be carried out previous to any efforts regarding the repopulation of acidified lakes with fish.

\section{ACKNOWLEDGEMENTS}

We'd like to express our gratitude to S. Fiori of the Cantonal Game and Fisheries Department for his efforts during the preliminary investigation. We are also most indepted to A.-M. Forss, M. Schlatter, and A. Dotti for their help with the stocking experiment. The analyses of the water samples were done at the Cantonal Laboratory in Bellinzona by Alessandro under the guidance of A. Barbieri and B. Polli. This study was financed by the Swiss National Research Foundation, grant No. 3.137-0.85.

\section{REFERENCES}

Baker, J.P. and C. L. Schofield, 1980. Aluminium toxicity to fish as related to acid precipitation and Adirondack surface water quality. Proc. Int. Conf. Ecol. Impact Acid Precip., Norway, SNSF-Project: 292-293.

Baker, J. P. and C. L. Schofield, 1982. Aluminium toxicity to fish in acidic waters. Water, Air, and Soil Pollution 18: 289-309.

Barbieri, A. and G. Righetti, 1987. Chimica delle deposizioni atmosferiche nel cantone Ticino ed effetti sulle acque dei laghi alpini d'alta quota. Doc. Inst. Ital. Idrobiol. 14: 19-34.

Barnes, R. B., 1975. The determination of specific forms of aluminium in natural waters. Chemical Geology 15: 177-191.

Birchall, J. D., C. Exley, J. S. Chappell and M. J. Phillips, 1989. Acute toxicity of aluminium to fish eliminated in silicon-rich acid waters. Nature $338: 146-148$.

Brown, D. J.A., 1981. The effect of sodium and calcium concentrations on the hatching of eggs and the survival of the yolk sac fry of brown trout, Salmo trutta L. at low pH. Fish Biol. 19: 205-211.

Burrows, W. D., 1977. Aquatic aluminium: Chemistry, toxicology, and environmental prevalence. CRC Critical Reviews in Environmental Control 7: 167-216.

Cronan, C. S. and C. L. Schofield, 1979. Aluminium leaching response to acidic precipitation: Effects on high-elevation watersheds in Northeast. Science 204: 304-306. 
Daye, P. G. and E. T. Garside, 1975. Lethal levels of pH for brook trout, Salvelinus fontinalis. Can. J. Zool. 53: 639-641.

Dietrich, D. R., 1988. Aluminium toxicity to salmonids at low pH. PhD Thesis No. 8715, Swiss Federal Institute of Technology, Institute of Toxicology, Zürich, Switzerland, $210 \mathrm{pp}$.

Dietrich, D. R., Ch. Schlatter, N. Blau and M. Fischer, 1989. Aluminium and acid rain: Mitigating effects of $\mathrm{NaCl}$ on aluminium toxicity to brown trout (Salmo trutta fario) in acid water. Toxicol. Environ. Chem. 19: 17-23.

Dietrich, D. R. and Ch. Schlatter, 1989. Aluminium toxicity to rainbow trout at low pH. Aquatic Toxicology: in press.

Discroll, C. T., J. P. Baker, J. J. Bisogni and C. L. Schofield, 1980. Effects of aluminium speciation on fish in dilute acidified water. Nature 248: 161-164.

Discroll, C. T., 1989. Personal communication.

Drablos, D. and A. Tollan (eds.) 1980. Ecological impact of acid precipitation. Proc. Int. Conf. Ecol. Impact Acid Precip., Norway, SNSF-Project.

Fivelstad, S. and H. Leivestad, 1984. Aluminium toxicity to atlantic salmon (Salmo salar L.) and brown trout (Salmo trutta L.): Mortality and physiological response. Institute of Freshwater Research, Drottningholm, Sweden. Report 61: 69-77.

Hutchinson, N. J., K. E. Holtze, J. R. Munro and T. W. Pawson, 1987. Lethal responses of salmonid early lifestages to $\mathrm{H}^{+}$and aluminium in dilute acidic waters. Annls. Soc. R. Zool. Belg. 117/1: 201-217.

Johnson, N. M., C. T. Driscoll, J. S. Eaton, G. E. Likens and W. H. McDowell, 1981. Acid rain, dissolved aluminium and chemical weathering at the Hubbard Brook Experimental Forest, New Hampshire USA. Geochim. Cosmochim. Acta 45: 1421-1437.

Johnson, N.M., 1984. Acid rain neutralization by geologic materials. In: Geologic Aspects of Acid Deposition. Ann Arbor Science Books, Ann Arbor, pp. 37-53.

Känzig, A., R. Knutti, Ch. Schlatter, U. Vogelsang and K. Zaruba, 1987. Aluminium transfer during dialysis. In: P. Brätter \& P. Schramel (eds.), Trace Element-Analytical Chemistry in Medicine and Biology, Vol. 4, Walter de Gruyter \& Co., New York, pp. 463-471.

LaZerte, B.D., 1984. Forms of aqueous aluminium in acidified catchments of Central Ontario: A methodological analysis. Can. J. Fish. Aquat. Sci. 41: 766-776.

Lehmann, J. and F.-J. Stürenberg, 1980. Techniken zur Blutentnahme bei Süßwassernutzfischen. Fisch und Umwelt 8: 77-88.

Leivestad, H., I. P. Muniz and B. O. Rosseland, 1980. Acid stress in trout from a dilute mountain stream. Proc. Int. Conf. Ecol. Impact Acid Precip., Norway, SNSF-Project, pp. 318-319.

Mallatt, J., 1985. Fish gill structural changes induced by toxicants and other irritants: A statistical review. Can. J. Fish. Aquat. Sci. 42: 630-648.

Marrer, H., 1986. Personal communication.

Muniz, I. P. and H. Leivestad, 1980 a. Acidification - effects on freshwater fish. Proc. Int. Conf. Ecol. Impact Acid Precip., Norway, SNSF-project, pp. 84-92.

Muniz, I. P. and H. Leivestad, 1980 b. Toxic effects of aluminium on the brown trout, Salmo trutta L. Proc. Int. Conf. Ecol. Impact Acid Precip., Norway, SNSF-Project, pp. 320-321.

Rickenbacher, U. J., 1984. Gastrointestinale Absorption und toxische Auswirkungen von Aluminiumverbindungen bei Versuchstieren und exponierten Personen, PhD-Thesis No.7480, Swiss Federal Institute of Technology, Institute of Toxicology, Zürich, Switzerland, $108 \mathrm{pp}$.

Righetti, G., 1981. Controllo sui laghi alpini del cantone Ticino. Aquicultura Ticinese 9: 10-11.

Rosseland, B. O. and O.K. Skogheim, 1984. A comparative study on salmonid fish species in acid aluminium rich water. II: Physiological stress and mortality of one and two year old fish. Institute of Freshwater Research, Drottningholm, Sweden, Report 61: 186-194.

Rosseland, B. O. and O. K. Skogheim, 1987. Differences in sensitivity to acidic soft water among strains of brown trout (Salmo trutta). Annls. Soc. R. Zool. Belg. 117/1: 255-264.

Skogheim, O. K., B. O. Rosseland and I. H. Sevaldrud, 1984. Deaths of spawners of atlantic salmon (Salmo salar L.) in River Ogna, SW Norway, caused by acidified aluminium rich water. Institute of Freshwater Research, Drottningholm, Sweden, Report 61: 195-202.

Skogheim, O. K. and B. O. Rosseland, 1986. Mortality of smolt of atlantic salmon, Salmo salar L., at low levels of aluminium in acidic soft water. Bull. Environ. Contam. Toxicol. 37: 258-265.

Stoeppler, M. and F. Backhaus, 1978. Pretreatment studies with biological and environmental materials. Fresenius Z. Anal. Chem. 291: 116-120. 
Water Analysis, 1983. Swiss Federal Guidelines for Water Analysis. 10.83400 A2327/2. Swiss Federal Department of the Interior.

Wright, R.F. and E. Snekvik, 1978. Acid precipitation: Chemistry and fish populations in 700 lakes of southernmost Norway. Verh. Internat. Verein. Limnol. 20: 765-775.

Wood, C. M. and D. G. McDonald, 1987. The physiology of acid/aluminium stress in trout. Annls. Soc. R. Zool. Belg. 117/1: 399-410.

Zobrist, J., L. Sigg, J. L. Schnoor and W. Stumm, 1986. Buffering mechanisms in acidified alpine lakes. In: COST 611 Workshop "On the reversibility of acidification", Grimstad, Norway, June 1986. 